\title{
OS SENTIDOS DA FESTA: MÁRIO MELO E AS ESCOLAS DE SAMBA NO CARNAVAL RECIFENSE (1955-1956)
}

\author{
THE SENSES OF THE FEAST: MARIO MELO AND THE SAMBA \\ SCHOOLS IN RECIFE CARNIVAL (1955-1956)
}

DOI: http://dx.doi.org/10.15448/2178-3748.2016.1.19982

\author{
Augusto Neves da Silva \\ Doutorando em História - UFF \\ augustonev@gmail.com
}

\begin{abstract}
RESUMO: O presente trabalho tem por objetivo analisar quais os motivos que levaram o jornalista Mário Melo, importante membro da intelectualidade pernambucana, e alguns de seus congêneres, a criticar a presença das escolas de samba no Carnaval do Recife. Por que para o referido intelectual o samba não poderia coexistir em meio a outras práticas culturais da folia recifense? Qual o sentido de tradição que estava defendendo para o festejo? O que estava em jogo para que o samba fosse condenado? Ao se procurar responder a essas perguntas, evidenciou-se uma cidade que se colocava em disputa pelo formato de festa desejado. E dar visibilidade a estes conflitos é compreender, naqueles "alegres" dias de Momo, não um campo de consenso harmônico, mas um meio de efetivação de embates entre diferentes práticas e tradições a serem legitimadas.
\end{abstract}

PALAVRAS-CHAVE: Escolas de Samba. Mário Melo. Carnaval em Recife.

ABSTRACT: This paper analyzes the reasons of journalist Mario Melo, a leading member of the Pernambuco intellectuals, and some of his peers, to criticize the presence of samba schools in the Carnival of the Recife. Why for the referred intellectual the samba could not coexist amid other cultural practices of the Recife's revelry? What is the sense of tradition that was advocating for the celebration? What was at stake for the samba was convicted? By seeking to reply to these questions, there was a city that was placed in contention for the desired party format. And give visibility to these conflicts is to understand, those "happy" days of Momo, not a harmonious consensus field, but a means of execution of clashes between different practices and traditions to be legitimized.

KEYWORDS: Samba Schools. Mario Melo. Carnival in Recife.

\section{Introdução}

As escolas de samba estão presentes na cidade do Recife desde a década de $1930 .{ }^{1}$ Durante muitos anos a prática cultural enfrentou uma espécie de invisibilidade. ${ }^{2}$ Quando digo que a história das escolas de samba e a dos sambistas passou por uma invisibilidade, refiro-me à ausência de estudos a respeito dessas manifestações e dessa gente.

\footnotetext{
${ }^{1}$ Sobre a história das escolas de samba no Recife ver SILVA, A. N. E o Recife sambou: disputas e conflitos em torno das primeiras escolas de samba. Saeculum (UFPB), v. 27, p. 123-141, 2012.

${ }^{2}$ Sobre o processo de invisibilidade histórica enfrentado pelas escolas de samba no Recife ver SILVA, A. N. Debate Historiográfico sobre as escolas de samba em Recife (1955 - 1970). Monografia de Conclusão de Curso (Bacharelado em História). Recife: UFPE, 2009.
} 
Os trabalhos que trataram sobre o tema lançaram as escolas de samba ao lugar de uma prática exógena, exótica e desviante da cultura local. ${ }^{3}$ Provavelmente o que a intelectualidade ${ }^{4}$ local não queria era a divulgação e a propagação de que na "Veneza Brasileira" havia samba. Não seria interessante, para um Estado em que se pregava um regionalismo ${ }^{5}$ tão forte com uma tradição carnavalesca pautada nos clubes de frevo, o conhecimento de que havia escolas de samba.

Vários membros da intelectualidade ${ }^{6}$ buscaram com seus escritos deslegitimar a prática das escolas de samba, as associando ao Rio de Janeiro e apontando que não deveriam existir em Pernambuco. Os intelectuais ${ }^{7}$ criaram uma espécie de campo de debates nos jornais ${ }^{8}$, com

\footnotetext{
${ }^{3}$ Sobre isso ver SILVA, Leonardo Dantas. Carnaval do Recife. Recife: Prefeitura da Cidade, 2000; SILVA, Leonardo Dantas (Introdução). Antologia do Carnaval em Recife. Mário Souto Maior e Leonardo Dantas Silva (Orgs). Recife: FUNDAJ, Editora Massangana, 1991. REAL, Katarina. O Folclore no carnaval do Recife. 2. ed. rev e aum. Recife: FUNDAJ, Editora Massangana, 1990; BENJAMIN, Roberto Câmara. Samba de Carnaval, In: Antologia do Carnaval em Recife. Mário Souto Maior e Leonardo Dantas Silva (Orgs). Recife: FUNDAJ, Editora Massangana, 1991; FREYRE, Gilberto. "Recifense, sim, sub-carioca, não". Jornal do Commercio, 27 de fevereiro de 1966, p. 4; FREYRE, Gilberto. "Recifense, sim, sub-carioca, não". Diário de Pernambuco, 27 de fevereiro de 1966, p. 4, I caderno.

${ }^{4}$ Partilho das colocações de Michel Löwy quando compreendeu a intelectualidade como "categoria social definida por seu papel ideológico: eles são os produtores diretos da esfera ideológica, os criadores de produtos ideológico-culturais", o que engloba "escritores, artistas, poetas, filósofos, sábios, pesquisadores, publicistas, teólogos, certos tipos de professores e estudantes, etc.". LÖWY, Michel. Para uma sociologia dos intelectuais revolucionários. São Paulo: Ciências Humanas, 1979, p. 01.

5 "O regionalismo é muito mais do que uma ideologia de classe dominante de uma dada região. Ele se apoia em práticas regionalistas, na produção de uma sensibilidade regionalista, numa cultura, que são levadas a efeito e incorporadas por várias camadas da população e surge como elemento dos discursos destes vários segmentos". ALBUQUERQUE JÚNIOR, Durval Muniz de. A Invenção do Nordeste e Outras Artes. 4. ed. rev. São Paulo: Cortez, pp. 38-39, 2009.

${ }^{6}$ Os principais nomes que compunham a intelectualidade recifense e escreviam nos jornais da época eram Mário Melo, Aníbal Fernandes, Alberto Campelo, José do Patrocínio, Valdemar de Oliveira e Leda Alves. Para saber mais: SILVA, A. N. Quem gosta de samba, bom pernambucano não é? Dissertação (Mestrado em História). UFPE: Recife, 2011. (Principalmente o capítulo II).

${ }^{7}$ Determinados indivíduos são ditos, entendidos e nomeados pela sociedade recifense da época a qual trabalho como intelectuais. Intelectual para esse momento histórico são aqueles sujeitos que escrevem nos jornais, ocupam cargos em instituições públicas importantes, produzem escritos, memórias, crônicas sobre o Recife, narram histórias sobre a cidade e o próprio Estado de Pernambuco. Ressalto que a categoria de intelectuais não é atemporal, nem homogênea, nem pode ser entendida como um grupo coeso, nem o ser intelectual representou a mesma coisa em todo o tempo. No entanto, não posso fugir a essa categoria, pois é dessa forma que esses indivíduos são entendidos e nomeados pela sociedade, de acordo com as matérias dos jornais. Sobre o papel e a função do intelectual na sociedade ver, entre outros: BOBBIO, Norberto. Os Intelectuais e o Poder. São Paulo: UNESP, 1997.

${ }^{8}$ Vários intelectuais publicaram escritos sobre o processo de oficialização do carnaval do Recife: OLIVEIRA, Valdemar. Oficialização do Carnaval. Diario de Pernambuco, 15 de janeiro de 1956, p. 6. Esta matéria foi lida também na Rádio Clube do Recife, no programa Crônica da Tarde; FERNANDES, Aníbal. Samba e "Guerra Fria". Diario de Pernambuco, 14 de janeiro de 1956, p. 4; FERNANDES, Aníbal. Carnaval e Turismo. Diario de Pernambuco. 5 de janeiro de 1956, p. 4; ALVES, Leda. Todos os dias: Carnaval Pernambucano. Correio do Povo, 24 de janeiro de 1956, p. 6; CAMPELO, Alberto. Coluna Freza Vida. Correio do Povo, 17 de janeiro de 1956, p. 3; PATROCÍNIO, José. Coluna Freza Vida. Correio do Povo, 18 de janeiro de 1956, p. 3; FREYRE, Gilberto. O Frevo em face do samba. Jornal do Commercio, 19 de fevereiro de 1956, p. 1. II Caderno.
} 
ideias validadas uns pelos outros. Um dos principais nomes nesse contexto foi o de Mário Melo 9 .

Mário Melo foi um jornalista pernambucano de forte influência na sociedade. Escrevia sobre muitos assuntos, inclusive a respeito do Carnaval: “[...] o papel do jornalista é esclarecer o povo a responsabilidade do inevitável futuro do Carnaval recifense [...] mesmo velho, ainda tenho força de gritar e converter minha terra”. (FOLHA DA MANHÃ, 15/01/1956, p. 4). Sobre a relação de Melo com as escolas de samba, a antropóloga Katarina Real (1990, p. 48) afirmou: "as escolas de samba começaram a crescer, sempre contra a violenta oposição da Federação Carnavalesca Pernambucana e alguns de seus fundadores, como o grande folclorista pernambucano, Mário Melo". Vale destacar que os escritos de Mário Melo não ficaram "apenas" no campo do debate, mas geraram tensões e conflitos na cidade. Mesmo já existindo uma Lei que oficializou o Carnaval do Recife, ${ }^{10}$ um Decreto-Lei ${ }^{11}$ foi criado para atender às reivindicações dos intelectuais.

O caminho eleito para a análise foi a leitura e a interpretação das matérias de jornais e das leis e decretos-leis municipais. Por meio destas fontes, meu olhar de percorreu sentidos que deram a ver alguns efeitos de verdades sobre o Carnaval no Recife, que não só construiu determinados sentidos para a festa, mas também buscou apagar ou tornar invisíveis outros. Tenho consciência de que essas fontes não representam o passado, mas vestígios dele, pois a documentação é repleta de sentidos e guarda marcas daqueles que a produziram, que a colocaram em evidência: "Nenhum objeto tem movimento na sociedade humana exceto pela significação que os homens lhe atribuem, e são as questões que condicionam os objetos e não o oposto". (SCHWARCZ, 2001, p. 7). Convido os leitores a acompanhar essa história. Vamos

\footnotetext{
${ }^{9}$ Mário Carneiro do Rego Melo nasceu a 5 de fevereiro de 1884, filho de Manoel do Rego Melo e de Maria da Conceição Carneiro da Cunha (Ciçone), no Sítio Barbalho, atual bairro de Iputinga, no Recife. Em 1907 graduou-se em Direito. Escreveu vários livros, entre eles: A Maçonaria e a Revolução de 1817 em 1912. A sua grande paixão era o jornalismo. Trabalhou nos jornais Folha do Povo, Correio do Recife, Jornal Pequeno, A Província, Diario de Pernambuco e Jornal do Commercio, dentre outros. Em 1948 foi eleito Deputado Estadual pela legenda do PSD. Participou da fundação da Universidade do Recife, como criador da Escola de Belas Artes e da Faculdade do Comércio e Ciências Econômicas, das quais foi professor. Membro do Instituto Arqueológico, Histórico e Geográfico Pernambucano (IAGHPE), presidente da Federação Carnavalesca, dentre outras entidades públicas. Morreu em 24 de maio de 1959. Sobre Mário Melo ver: ROSTAND, Paraíso. Cadê Mário Melo. Recife: COMUNIGRAF, 1997.

${ }^{10}$ A Lei 3.346 de 07 de junho de 1955, sancionada pelo prefeito Djair Brindeiro, teve por objetivo determinar que a partir de 1956 a Prefeitura do Recife iria entregar um valor anual às agremiações participantes do festejo, como também custear a decoração das ruas para o carnaval da cidade. Essa lei e outras leis e decretos-leis encontram-se disponíveis no site http://www.legiscidade.recife.pe.gov.br. Acesso em 17de maio 2015.

${ }^{11}$ Em virtude da pressão dos intelectuais, a Lei 3.346 de 7 de junho de 1955 foi modificada por meio do DecretoLei $\mathrm{N}^{\circ} .1 .351$ de 23 de janeiro de 1956. Por meio deste último, as agremiações desfilantes no carnaval continuariam a contar com uma verba dos cofres públicos, mas a partir daquela data respeitando uma classificação na qual as escolas de samba figurariam na última posição. Mais adiante retornarei à questão. Lei e Decreto-Lei disponíveis em: http://www.legiscidade.recife.pe.gov.br. Acesso em 18 jan. 2015.
} 
percorrer as trilhas e conhecer uma Recife repleta de conflitos e tensões, visualizar uma cidade que se colocava em meio às disputas pelo formato de festa carnavalesca desejado.

\section{Qual o "Mistério do Samba" no Recife?}

Tomando de empréstimo o título do trabalho de Hermano Vianna (VIANNA, 2007), inicio esta discussão perguntando: qual o "mistério do samba" no Recife? Em 1955, por meio da Lei Municipal No. 3.346/55 - que oficializou o Carnaval recifense -, o samba foi incluído como uma das práticas culturais da capital pernambucana, que se apresentaria por meio das escolas de samba durante do reinado de Momo. No entanto, essa inclusão não foi bem vista por parcela dos intelectuais. O que estava em jogo para que parte consistente da intelectualidade criticasse a presença desse segmento no Carnaval da cidade?

Interpreto que o "mistério" enfrentado pelo samba e pelas escolas de samba no Carnaval da cidade foi o fato dessas práticas culturais estarem associadas a fenômenos oriundos do Rio de Janeiro. Para a intelectualidade, a permanência dessas manifestações culturais no Carnaval iria corroê-lo, transformando o que eles denominavam de legítimo, autêntico e tradicional da festa local numa cópia dos festejos carnavalescos da "cidade maravilhosa". Para esses intelectuais, como o jornalista Aníbal Fernandes ${ }^{12}$, os carnavais deveriam guardar suas particularidades, cada localidade preservando suas especificidades. Escola de samba é uma prática associada ao Rio de Janeiro e por essas terras deveria ser valorizada e propagada. Em Pernambuco o que deveria se incentivar eram clubes de frevo, maracatus e caboclinhos.

[...] O carnaval do Recife deve ser tipicamente nosso, o que há de estimular são os maracatus, os bumba-meu boi, os frevos, os antigos clubes e cordões com seus estandartes e as suas bandeiras e as suas tradicionais fantasias. Não seria indicado, por exemplo, estimular, no Recife, escola de samba: simplesmente porque isso não é recifense, é carioca. As melhores escolas de samba são as do Rio de Janeiro; e o samba desce das favelas, como o frevo

\footnotetext{
${ }^{12}$ Aníbal Gonçalves Fernandes nasceu em Nazaré da Mata, no dia 30 de dezembro de 1894, em Pernambuco. Filho do casal Albino Gonçalves Fernandes e Maria Luzia Lobo Guido Fernandes. Aníbal Fernandes fez seus estudos no Seminário de Olinda e na Faculdade de Direito do Recife, tendo concluído o curso superior em 1916. Foi professor do Ginásio Pernambucano, da Faculdade de Filosofia do Recife, diretor do Museu do Estado e da Inspetoria de Monumentos Artísticos. Entretanto encontrou no jornalismo sua plena e verdadeira vocação. Em 1912 passou a ser revisor do Jornal de Pernambuco. Em 1914, no dia 17 de julho, se transferiu para o Diário de Pernambuco, permanecendo no periódico até 1952 quando se aposentou, mas continuou escrevendo para o jornal. Faleceu em 12 de janeiro de 1962 com 68 anos de idade. Sobre Aníbal Fernandes ver FERRAZ, Marilourdes. Aníbal Fernandes: jornalista - Nos caminhos da liberdade. Associação da Imprensa de Pernambuco. Recife: CEPE, 1996.
} 
desceu dos mocambos [...]. (DIARIO DE PERNAMBUCO, 05/01/1956, p. 4).

O que estava em disputa era a invenção ${ }^{13}$ de um projeto de Carnaval para a cidade e o discurso - de negação do samba e afirmação do frevo como "ritmo da terra"14 ${ }^{14}$ de intelectuais, como o jornalista Aníbal Fernandes, era um mecanismo importante dentro da construção desse projeto. Em meio à disputa do título de "melhor Carnaval" do Brasil, o modelo da festa desejada para o Recife se contrapunha ao que era praticado no Rio de Janeiro. Essa escolha de parte da intelectualidade recifense refletia questões políticas: ao incorporar o discurso das escolas de samba como uma prática carioca, relegava-se aos sambistas pernambucanos o lugar social do exilado, do estrangeiro no próprio Estado. Os sujeitos que faziam samba no Recife eram malvistos e criticados como propagadores de uma cultura estrangeira.

Diante disso, o samba não foi entendido como manifestação passível de ser constituída como o resultado de práticas diversas produzidas no Recife. Era-lhe relegada uma origem carioca e aqui residia o problema, pois para os intelectuais do período (1955-1956) só poderia representar o Carnaval recifense aquilo que estivesse associado ao Estado de Pernambuco. Como o samba e as escolas de samba foram construídas como um produto que remete ao Rio de Janeiro, deveriam ser condenados.

\section{Traduzindo a Tradição}

Um tema importante dentro desse debate é o conceito de tradição, ou, como a maioria dos intelectuais gostava de proclamar, "a defesa da legítima tradição carnavalesca recifense". Ressalte-se que essa tradição não era entendida apenas no sentido antropológico (Antropologia Cultural) como regras, hábitos e costumes, mas numa visão mais conservadora, composta de aspectos que resistem à mudança e aos quais se imputam valores que devem ser preservados, muitas vezes almejando a construção de um passado forjado.

\footnotetext{
13 "Inventar [...] não é fraudar, mentir, fazer surgir do nada, mas é inseparável da atividade de significação das coisas, dos seres, das formas, de tudo aquilo que nomeamos. Nomear, ato fundante do mundo humano, é já conceituar.", visto que quando - sejam as pessoas que representavam o poder público, sejam os intelectuais - se nomeavam uma atividade como integrante do que era entendido como o carnaval do Recife, quem assim fazia a inventava como tal, "pois estava, nesse ato, deslocando os sentidos que essa prática poderia e, com certeza, já deveria ter para seus praticantes e a dotava de novos significados". ALBUQUERQUE JÚNIOR, Durval Muniz de. "Um morto vestido para um ato inaugural": procedimentos e práticas dos estudos de folclore e cultura popular. São Paulo: Intermeios, 2013, p. 27-28.

${ }^{14}$ Sobre a invenção do frevo como um "ritmo da terra" ver ARAÚJO, Rita de Cássia Barbosa de. Festas: Máscaras do Tempo. Entrudo, mascarada e frevo no carnaval do Recife. Recife, Fundação de Cultura da cidade do Recife, 1996.
} 
A noção de tradição possui problemas epistemológicos que devem ser levados em consideração. Naquilo que se define como tradição observa-se uma tentativa da permanência do passado no presente. Mais: elas são discriminatórias, pois "tendem a constituir um sistema de referências que estabelece distinções entre o que é tradicional e o que não é. Inscrever-se numa tradição significa, portanto, marcar uma diferença, sendo preciso interrogar as funções políticas das tradições”. (CAPONE, 2004, p. 29).

Falar de uma tradição carnavalesca recifense "pura" incita a refletir a respeito de um objeto postulado como dado e natural. No entanto, seus contornos nem sempre são bem definidos. Hobsbawm e Ranger ressaltaram a construção presente em toda a tradição, criando a noção de "tradições inventadas". ${ }^{15}$ Com isso mostraram que as tradições são reações a situações novas que assumem a forma de referência a situações anteriores ou estabelecem seu próprio passado através da repetição. (HOBSBAWM; RANGER, 2008, p. 10).

Inventar tradições significa criar rituais e regras que busquem traçar uma continuidade com o passado, criando uma memória que funcione com um estoque de lembranças. Deve-se entender que nem tudo que a "tradição inventada" abarca é realmente passado; várias de suas manifestações são recentes, mas surgem para as pessoas como há muito existente. Falar em "tradições inventadas" pode parecer redundante, haja vista que os homens estão sempre a criar, recriar, inovar, transformar suas ações em sociedade: "Tradições seriam, por definição, continuamente reinventadas em função das sempre renovadas conjunturas do presente" (SANDRONI, 2013, p. 30).

A invenção da tradição carnavalesca recifense - como um mecanismo de retorno a um "passado original" -, pode ser vista como um acontecimento que buscou produzir sentidos de autenticidade para a festa. Que circunstâncias fazem com que se busque restabelecer essa tradição? Isso está atrelado ao processo de perda da tradição em face das mudanças determinadas pelo avanço da modernidade. Essa perda é o motor do retorno às origens cujo objetivo principal é reconstruir um estado original. Como afirmou a antropóloga Stefania Capone:

[...] quem possui uma tradição possui um passado, uma continuidade histórica que a metamorfoseia em sujeito de sua própria história: afirmar sua tradicionalidade equivale a se distinguir dos outros, aqueles que não tem mais identidade definida. Construir sua própria representação do passado - a

\footnotetext{
${ }^{15}$ Segundo Eric Hobsbawm: "Por tradição inventada entende-se um conjunto de práticas, normalmente reguladas por regras tácitas ou abertamente aceitas, tais práticas, de natureza ritual ou simbólica visam inculcar certos valores e normas de comportamento através da repetição, o que implica automaticamente uma continuidade em relação ao passado". HOBSBAWM, Eric. RANGER, Terence. (Org.) A Invenção das Tradições. 6. ed. Rio de Janeiro: Paz e Terra, p. 9, 2008.
} 
tradição - passa a ser assim um meio de negociar a posição ocupada na comunidade em questão. (CAPONE, 2004, p. 255-256).

Falar em tradição implica referir-se à operacionalização do passado no presente com o objetivo de conservá-lo. Deve-se destacar também que as tradições não são um simples reservatório de ideias, mas um modelo de interação social por meio da qual se constroem as identidades, operacionalizando uma seleção de determinados elementos que ajudem a estabelecer as diferenças entre "nós" e "outros". Os intelectuais desempenham papel central nesse processo como os defensores de "certos" projetos ideológico-culturais.

Quando foca-se demais a atenção no papel desempenhado pelos intelectuais na construção das tradições, esquece-se da ação dos sujeitos simples, das pessoas comuns que vivenciam e significam as práticas culturais como se fossem indivíduos inertes e receptores passivos nesse processo e as tradições, produtos inventados pelos intelectuais, como mediadores culturais ${ }^{16}$. Deve-se compreender que a legitimação histórica das tradições é fruto de diálogos travados entre diferentes grupos, internos e externos, mediados por interesses e ideologias diversas.

Prefiro pensar em tradições no plural. Acredito ser preciso distinguir o que os intelectuais definiam como tradição, da que era vivida e significada pelos sujeitos que se envolveram com determinadas manifestações culturais. É necessário reconhecer nesses indivíduos o direito de criar, de compor, de ter suas próprias tradições. Dito de outra forma, a apropriação feita pelos intelectuais das tradições nem sempre corresponde ao que foi incorporado e vivenciado pelos atores sociais das práticas culturais (GUILLEN, 2003). Proponho analisar a tradição como dotada de sentidos mais amplos, a partir dos quais ela não seja vista como um dado homogêneo e limitador das práticas culturais, mas como uma espécie de resposta ao seu tempo. Por vezes, a definição de um aspecto "tradicional" não pode ser colocada como um dado natural diante do sentido de todas as práticas culturais existentes. Destarte, as maneiras pelas quais uma tradição é evocada devem ser consideradas, haja vista que discursos sobre tradição podem ser usados para os mais variados propósitos. Falar de tradição não significa unicamente pensar que o que se faz hoje se fez no passado, mas está ligado ao que espera poder continuar a se fazer no presente e no futuro.

\footnotetext{
${ }^{16}$ Os mediadores culturais foram assim definidos por Michel Vovelle: "posso logo afirmar que é em termos dinâmicos que entendo o intermediário cultural, como seu próprio nome sugere, transitando entre dois mundos". $\mathrm{O}$ mediador cultural assume diversas feições. Situado entre o universo dos dominantes e dominados, adquire uma posição excepcional e privilegiada, ambígua também, na medida em que pode ser visto tanto no papel de cão de guarda das ideologias dominantes, como porta-voz das revoltas populares. (VOVELLE, Michel. Os Intermediários Culturais, In: Ideologias e Mentalidades. Tradução de Maria Julia Cottvasser. 2. ed. São Paulo: Brasiliense, 1991, p. 207-239).
} 
Tradições são relações de poder. Constroem autoridades, determinam legitimidades e tornam memórias processos autênticos do presente. Transformam símbolos recentes em "verdadeiros" elementos de coesão social e de identidade. Discutir tradição é falar de um poder ideológico com a capacidade de determinar o sentido da realidade, impor valores e narrar a história a partir de sua própria perspectiva. ${ }^{17}$

\section{Com que samba eu vou pra folia que você me convidou?}

De acordo com Hermano Vianna, o samba como um produto nacional e mestiço, que teve o Rio de Janeiro como lócus irradiador, é resultado de uma invenção. Não nasceu autenticamente nacional e nem mestiço, mas foi sendo autenticado aos poucos como tal durante os anos de 1920 e $1930^{18}$. A ideia central de Vianna (2007) está "no processo de invenção de uma tradição do samba como expressão social de raiz". Para o pesquisador, este processo foi uma das bases fundamentais da mediação cultural pelo qual o samba passou "de música marginal a louvada e brasileira por excelência” (VIANNA, 2007, p. 145-158).

Apesar da relevância dos estudos de Hermano Vianna, partilho a concepção da historiadora Maria Clementina Pereira Cunha (2001) quando salientou o fato de o autor dar muita importância ao papel desempenhado pelos intelectuais como mediadores culturais responsáveis pela criação e reinvenção do samba, pois, dessa forma, retira-se a possibilidade de se compreender os diálogos travados entre diferentes grupos dentro desse processo e visualizar as tensões e os conflitos gerados pelas diferenças sociais e culturais.

O samba não nasceu pronto, mas foi fruto de um processo construído pelo diálogo com diferentes práticas que foram compondo sua feição moderna ${ }^{19}$. Contrariando a versão de Hermano Vianna (2007) de uma invenção mestiça e nacional para o samba como resultado do intercâmbio entre diferentes grupos sociais, há outra vertente que defende a concepção do samba como a herança indelével e intrínseca de uma cultura afro-brasileira guardada nas

\footnotetext{
${ }^{17}$ COUTINHO, Eduardo Granja. Velhas Histórias, memórias futuras: o sentido da tradição em Paulinho da Viola. 2. ed. ver. e ampl. Rio de Janeiro: Eidtora da UFRJ, 2011, p. 34.

${ }^{18}$ Segundo Hermano Vianna, "O samba surgiria como fruto do diálogo entre grupos heterogêneos que, cada um com seus propósitos e à sua maneira, criam ao mesmo tempo a noção de uma música nacional. Antes e fora deste processo nunca teria existido um samba pronto, autêntico, depois transformado em música nacional. O samba, como estilo musical, vai sendo criado concomitantemente à sua nacionalização". (VIANNA, Hermano. $O$ Mistério do Samba. 6. ed. Rio de Janeiro, Jorge Zahar Editores, UFRJ, 2007, p. 151). Além do estudo de Hermano Vianna ver também CUNHA, Fabiana Lopes da. Da Marginalidade ao estrelato. O Samba na construção da Nacionalidade (1917 - 1945). São Paulo: Annablume, 2004; MOURA, Roberto M. No Principio era a roda: um estudo sobre samba, partido alto e outros pagodes. Rio de Janeiro: Rocco, 2004; SANDRONI, Carlos. O Feitiço Decente. Transformações do Samba no Rio de Janeiro (1917 - 1933). Rio de Janeiro: Jorge Zahar Ed. : Ed. da UFRJ, 2001.

${ }_{19}$ Sua feição moderna refere-se às mudanças do começo do século XX no Rio de Janeiro, moldadas historicamente pelo "pessoal" do Estácio que o samba enfrentou.
} 
senzalas e nos morros cariocas, denominada pelo pesquisador Carlos Sandroni (2001) de concepção tópica.

Nesta, o samba não teria sido inventado, muito menos por 'vários grupos sociais'; ele já existia confinado às noites da senzala, dos terreiros de macumba ou dos morros do Rio de Janeiro, antes de sair à luz do dia e conquistar o Brasil. O 'lugar' do samba seriam os redutos da cultura negra, nichos onde esta se refugiou e resistiu (SANDRONI, 2001, p. 114).

Para Sandroni, quanto mais se enfatiza a cultura negra como o lugar por excelência do samba, mais a relação deste com a cultura branca será marcada pela repressão. Já na versão oposta, o samba mestiço como invenção, vê-se nele uma música neutra, "despida de marcas culturais potencialmente conflitivas" (SANDRONI, 2001, p. 114). Caso leve-se em consideração a hipótese do samba enquanto herança dos negros, não poderia ser ele uma prática cultural pernambucana?

A este respeito vale destacar que foi em Pernambuco que apareceu uma das primeiras referências da palavra samba associada a ritmo e dança: "tão agradável he (sic) um samba d'almocreves $^{20}$, como a Semiramis, a Gaza-ladra, o Tancredi, e \&c. de Rossini” (O Carapuceiro apud: TINHORÃO, 2008, p. 87). Vale salientar que essa prática de samba não era a mesma feita pelas escolas no Recife durante os anos de 1950 visto que as culturas são múltiplas e dinâmicas. A partir dessa informação, questiona-se que o samba como prática cultural já existia em Pernambuco há muitos anos e não seria fruto de um processo de transposição advindo do Rio de Janeiro em meados do século XX, como foi mencionado em algumas obras. $^{21}$

A tese do historiador Ivaldo Marciano de França Lima (LIMA, 2010) vem corroborar com o debate em torno do começo do samba na capital pernambucana. Lima demonstra que desde os últimos anos do século XIX e início do XX já havia licença de Carnaval para grupos de samba desfilarem. Sobre essas agremiações, afirmou que não há muito a informar, nem condições de descrevê-las, tampouco analisá-las, devido à inexistência de imagens e registros fonográficos. Também não se sabe sobre o tipo de samba que faziam, os instrumentos que utilizavam, nem quais os motivos que levavam a denominar-se de grupos de samba, marcando uma diferenciação em relação às demais agremiações do Carnaval na cidade (LIMA, 2010, p. 214).

\footnotetext{
${ }^{20}$ Para o padre Lopes Gama, autor do jornal humorístico O Carapuceiro, o samba d'almocreves representava o gosto das camadas mais baixas da sociedade, era o batuque dos negros. A palavra almocreves era relacionada a quem lidava com mulas.

${ }^{21}$ Sobre isso ver nota três.
} 


\section{Carnaval:}

Já estão devidamente licenciados pelo Sr. Dr. Chefe de polícia os seguintes clubs carnavalescos, que deverão percorrer as ruas da capital, nos próximos dias:

[...] Sambas - Quatro de Ouro, 3 de Ouro, Flor do Dia. (LIMA, 2010 p. 240).

\section{Gazetilha. Clubs e sociedades carnavalescas.}

Na Secretaria de Polícia pediram e obtiveram licença para percorrer as ruas da capital, hoje, amanhã e depois, os seguintes clubs e sociedades carnavalescas:

[...] Samba Trez de Ouro - Director, Paulo José Pinheiro; sede - Rua de São João.

[...] Samba Trez Estrellas - Director, Joaquim José da Costa; sede - Rua do Príncipe, 28.

[...] Samba Flor do Dia - Director, José Severiano de Andrade; sede - Rua da Matriz, 38 (Boa Vista).

[...] Samba Primeiro Anno - Director, João Romão de Sá Peixoto; sede -

Rua da Jangada (Segundo Districto de São José).

[...] Samba Flor da Aurora - Director, Lourenço André da Silva; sede - Rua do Feitosa (Belém).

[...] Samba Dois de Dezembro - Directora Maria Joaquina do Espírito santo; sede - Rua da Guia, 42. (LIMA, 2010, p. 240).

Bernardo Alves, memorialista e pesquisador, defendeu a ideia de que o samba nasceu em Pernambuco e era sertanejo, nordestino e indígena (ALVES, 2002, p. 281). Afirmou que os grupos de samba estavam presentes no Carnaval no Recife desde a segunda metade do século XIX.

O Samba, que era o forte do carnaval do Recife, na segunda metade do século XIX, era a cor local, sua característica mais expressiva, juntamente com o maracatu, entrou em decadência devido à migração de trabalhadores para o sul e à ascensão do frevo. A relação acima, baseia-se nas licenças para desfilar, exigida pela polícia a partir de 1886. Visto que só a partir desse ano é que foram exigidas tais licenças, esses Sambas que já desfilavam há décadas no nosso carnaval, quase não deixaram registros de sua trajetória anterior (ALVES, 2002, p. 266).

Para Alves (2002), os grupos de samba eram, em sua maioria, constituídos por pessoas oriundas do sertão que, além da viola e do pandeiro, utilizavam outro instrumento, a botija. Segundo o pesquisador: "Dela, tirava-se um som rechinado ou por vezes tamborilado, o qual se conseguia com a ajuda de um pedaço de metal, fosse uma chave, um prego grande ou uma moeda" (ALVES, 2002, p. 121). Para reverberar sua afirmação, mencionou algumas matérias de jornais que circulavam na cidade no período. 
Os sambas eram formados pela colônia sertaneja. Traziam entre oito e dez músicos que tocavam em maioria instrumentos de cordas, mas constava também pandeiro e um grande e quadrado tamborim (ALVES, 2002, p. 269).

Essa análise toma como evidente as informações contidas nas matérias de jornais e não questiona o seu conteúdo: "Máscaras e sertanejos que sambam, chocalhos batem, vaqueiros vestidos de couro galopam” (ALVES, 2002, p. 269). Assim, assume as informações como reais, não busca as redes que as instituíam, tampouco os interesses que as legitimavam. Além disso, a afirmação de que a maioria dos grupos de samba era constituída por sertanejos não é partilhada por outros pesquisadores, como é o caso de Clarissa Nunes Maia (MAIA, 2008). Segundo a historiadora, existia nesses grupos forte presença de negros em sua formação.

A outra forma de ajuntamento que as posturas municipais tentaram coibir
referiu-se aos chamados "batuques" ocorridos em casas de comércio, casas
particulares ou mesmo em casas chamadas especificamente de "casas de
batuque" ou "casas de samba". "Batuque" era como as danças e músicas dos
negros eram designadas de forma depreciativa pelo uso que faziam dos
tambores. O termo "samba" só veio a ser usado como sinônimo em fins do
século XIX (MAIA, 2008, p. 102-103).

Compreende-se que o objetivo central do livro de Alves era a desconstrução da concepção do samba como uma prática carioca e negra. Dessa forma, entende-se o fato de ele ter depositado relevante credibilidade às informações, colhidas junto aos jornais, que diziam o samba como um produto associado ao nordeste e aos indígenas, com o estado de Pernambuco como lócus dessa irradiação e espaço originário desse processo. No entanto, "deve-se romper com essa verdade evidente das coisas, como se o mundo fosse algo pronto e acabado, passível de ser descoberto, visto que as palavras, ao serem enunciadas, não oferecem por si a verdade" (MONTENEGRO, 2010, p. 30).

$\mathrm{Na}$ construção da trama histórica não se deve tomar discursos e nenhum outro documento como portadores da verdade. No que tange às falas jornalísticas, deve-se levar em consideração a imensa capacidade de alguns jornalistas criarem histórias. Num trabalho histórico, vai-se em busca de fios que engendravam acontecimentos, de redes que os instituíam, pois as "coisas não trazem em si mesmas um único significado, nem gritam ou mesmo dizem o que significam. As evidências são levadas a dizer algo por quem as disse, são levadas a serem vistas por quem as põe em evidência" (FOUCAULT, 1979, p. 5).

O que me propus a tentar demonstrar que o samba no Recife não pode ser entendido como transposto do Rio de Janeiro. Não se pode negar, todavia, que houvesse diálogos com o 
samba carioca. No entanto, a sua prática no Recife foi sendo feita e refeita pelos sujeitos sociais que a significavam na cidade e é nisso que se deve deter: nos usos e nas apropriações que os sambistas deram ao samba em Pernambuco. Procurodesmistificar os sentidos unívocos que relacionaram o objeto à palavra,os sentidos que associavam o samba e as escolas de samba à cidade do Rio de Janeiro. A análise histórica tem como pressuposto "as relações, os significados, as práticas, os fios, que são associados a acontecimentos para que assim possa construir formas de entendimento histórico" (MONTENEGRO, 2010, p. 31). Dentro dessa perspectiva, concordo com Foucault quando propõe rachar as palavras, desnaturalizá-las para ir em busca do que significam, "diferenciar as redes e os níveis a que pertencem e reconstituir os fios que os ligam e que fazem com que se engendrem, uns a partir dos outros" (FOUCAULT, 1979, p. 5).

\section{O Carnaval da Prefeitura}

O Carnaval recifense foi palco de inúmeras disputas. Os representantes do poder público municipal, bem como os membros da intelectualidade local, discorreram nesses anos (1955-1956) sobre o destino que os dias de Momo deveriam seguir. Ressalto que as escolhas feitas não foram frutos do acaso, mas foram tentativas de intervenções políticas e culturais específicas para a festa momesca, as quais se constituíram como situações históricas relevantes para quem se dedica a analisar a folia.

No ano de 1955 os dias de Momo foram oficializados pela Prefeitura do Recife. As agremiações carnavalescas contariam com uma verba dos cofres públicos para custear parte das despesas com suas apresentações durante os festejos em homenagem ao deus da galhofa.

Art. $1^{\circ}$ A Prefeitura Municipal do Recife, por intermédio do Departamento de Documentação e Cultura, organizará, patrocinará e promoverá os festejos carnavalescos do Município, a partir do ano de 1956, dentro dos moldes folclóricos, preservando sôbretudo: os clubes de frêvo; os maracatús, em sua forma primitiva e os clubes de caboclinhos (LEI MUNICIPAL $\mathrm{N}^{\circ}$ $3.346 / 1955)$.

Esse acontecimento pode ser visto como mais uma tentativa das elites de controlar a cidade, de normatizar os divertimentos populares. Visto que durante os festejos momescos ocorrem aglomerações de homens e mulheres nas ruas, toda essa quantidade de foliões podia representar um perigo se não fossem normatizados e determinadas as regras para quem quisesse participar da festa. 
Nota-se que, inicialmente, o processo de oficialização dos dias de Momo pela Prefeitura do Recife não fazia distinção entre as agremiações. Todas que se apresentavam durante os dias de folia teriam direito a uma verba dos cofres públicos dividida de forma igualitária.

Art. $4^{\circ}$ Será consignada no orçamento do Município do Recife, anualmente, a partir do ano de 1956, no quadro do Departamento de Documentação e Cultura, a dotação de hum milhão de cruzeiros $(\mathrm{Cr} \$ 1.000 .000,00)$ para fazer face às despesas com a organização, patrocínio e animação do carnaval do Recife, cuja importância deverá ser entregue ao referido Departamento, quinze (15) dias antes do início das festividades carnavalescas.

$\S 1^{\circ}$ Sessenta por cento $(60 \%)$ dessa verba será distribuída às agremiações com existência legal, de acôrdo com a classificação prévia, sendo a primeira cota antes do carnaval e a segunda depois, se comprovada a despesa da primeira cota após a exibição do Clube, reservando-se os quarenta por cento (40\%) restantes para ornamentação, iluminação, divulgação, propaganda e animação das festas carnavalescas. (LEI MUNICIPAL No 3.346/1955).

A Lei salientou que o órgão responsável pela organização do Carnaval, o Departamento de Documentação e Cultura, deveria ajudar técnica e financeiramente as escolas de samba, pois elas contribuíam para animação do Carnaval da cidade. Incluiu também a União das Escolas de Samba como uma das entidades auxiliares na organização do Carnaval.

Art. $5^{\circ}$ A Federação Carnavalesca Pernambucana, a Associação dos Cronistas Carnavalescos do Recife, a União das Escolas de Samba de Pernambuco e outras organizações carnavalescas porventura existentes, serão consideradas como entidades auxiliares do Departamento de Documentação e Cultura na organização do Carnaval do Município do Recife. (LEI MUNICIPAL No . 3.346/1955).

Para Mário Melo, o maior equívoco da referida Lei consistia exatamente no fato de incluir a União das Escolas de Samba entre as entidades auxiliares da organização dos festejos de Momo:

Como se fosse pouco, se não bastasse a oficialização das Escolas de Samba, organizou esse conselho eleitoralmente um representante da Federação, um representante dos Cronistas, um das Escolas de Samba e três da Rua da Guia. De início, quatro votos do Conselho, um do samba e três da Rua da Guia, contra dois. (JORNAL DO COMMERCIO, 15/01/56, p. 2).

Assim que chegou ao poder municipal, em janeiro de 1956, o prefeito Pelópidas Silveira convocou os vereadores para rever a lei aprovada em 1955 que ditava sobre os festejos de Momo. Segundo Pelópidas, a Lei No 3.346/55 não preservava o tradicionalismo histórico da festa carnavalesca recifense e precisava ser revista. Muitos vereadores recusaram- 
se a realizar tal ato, pois, conforme relatavam os jornais, achavam desnecessário modificar a lei, uma vez que esta já havia sido aprovada recentemente.

[...] Em defesa dos recifenses, o Prefeito Pelópidas Silveira convocou extraordinariamente a Câmara da Rua da Guia, para reexaminar o assunto, expurgando da oficialização as Escolas de Samba. Insistindo em colocar-se contra os recifenses, de que são indignos representantes, os vereadores deliberaram não atender ao Prefeito. Querem a oficialização do samba no carnaval recifense, porque nas <Escolas>, que consideram elementos de cultura (!!!) - assim figuram no orçamento municipal - contam com eleitorado. Entende o Prefeito, e entende muito bem, que não deve empregar o dinheiro dos recifenses com a descaracterização de seu carnaval, mesmo porque seu antecessor deixou o tesouro municipal como terra queimada. E assim, acertadamente, não despenderá um centavo com o carnaval. De tudo isso resulta que, ou a Câmara Municipal conserta seu erro para ser prestigiado somente o que se enquadra no folclore recifense, ou por culpa dos Vereadores da Rua da Guia, à falta de amparo monetário, os cordões de frevo, os maracatus e caboclinhos serão privados de exibir-se. (JORNAL DO COMMERCIO, 19/01/56, p. 2).

Em virtude da pressão feita pelo prefeito eleito em 1956, Pelópidas Silveira, e de intelectuais, como Mário Melo, a Lei $N^{o} 3.346 / 55$ foi revista e o Decreto Lei $\mathrm{N}^{\circ} 1.351$ foi sancionado em 23 de janeiro de 1956, preconizando que as agremiações carnavalescas receberiam uma verba dos cofres públicos municipais. Entretanto, obedeceriam a uma classificação segundo a qual as escolas de samba figurariam na última posição, recebendo apenas $5 \%$ do valor destinado. ${ }^{22}$

Acredito que seja importante procurar compreender o jogo da tradição carnavalesca em que intelectuais estavam imersos, entender como alguns de seus escritos foram recebidos, bem como analisar a rede de relações que lhes dava sustentação. Convido os leitores a mergulharem no debate promovido por um dos principais intelectuais desse período, o jornalista Mário Melo, e conhecerem os motivos elencados para tecer críticas à presença das escolas de samba na lei que oficializou os dias de Momo na capital pernambucana.

\section{Mário Melo e o seu "Tradicionalismo Histórico da Festa Carnavalesca Recifense"}

$\mathrm{Na}$ pesquisa realizada pude interpretar que, dos intelectuais que criticavam a presença das escolas de samba no Carnaval recifense, o que mais vezes escreveu nos jornais, e de

\footnotetext{
${ }^{22}$ A verba orçamentária destinada ao carnaval recifense deveria ser utilizada da seguinte maneira: $40 \%$ para atender a organização, iluminação, propaganda e animação dos festejos e $60 \%$ para os prêmios em dinheiro e aquisição das taças referentes aos concursos previstos no artigo anterior e seus parágrafos e para a distribuição às agremiações com existência legal, observando-se, nessa distribuição, as seguintes porcentagens: Clubes 35\%; Blocos 20\%; Maracatus 15\%; Caboclinhos 15\%; Troças e Ursos 10\% e Escolas de Samba 5\%. Decreto Lei No. 1.351/56. Disponível em: http://www.legiscidade.recife.pe.gov.br. Acesso em 18 jan. 2015.
} 
forma mais enfática contra o samba foi Mário Melo. Era um jornalista atuante. No ano de 1956 prestava serviços para dois periódicos da capital pernambucana, a Folha da Manhã e o Jornal do Commercio. Melo acreditava serem as escolas de samba manifestações prejudiciais à folia de Momo da cidade, bem como as considerava um espúrio à tradicional festa local.

O memorialista e ex-deputado estadual Mário Melo recorria constantemente aos jornais durante o período da revisão da lei que oficializou os festejos carnavalescos pela Prefeitura do Recife para criticar a forma como este processo estava sendo conduzido. Diante da recusa do poder legislativo em comparecer às reuniões convocadas pelo novo prefeito, Pelópidas Silveira, para rever a lei anteriormente sancionada, ele criticou incisivamente a atitude dos vereadores acusando-os de defender redutos eleitoreiros quando inseriram as escolas de samba no projeto que oficializava o Carnaval. (JORNAL DO COMMERCIO, 15/01/56, p. 2).

Melo era influente e, talvez, capaz de convencer não só os vereadores como também a própria sociedade sobre os problemas apontados por ele que seriam gerados com a inclusão das escolas de samba no processo de oficialização do Carnaval. Para ele, essas práticas culturais iriam descaracterizar e matar a folia recifense, pois, "equivaliam a uma espécie de câncer no maior e mais sublime símbolo da cultura pernambucana, o frevo". (JORNAL DO COMMERCIO, 17/01/56, p. 2).

[...] incentivar o samba pelo Carnaval, é trabalhar contra o frevo. É tirar o frevo do Carnaval pernambucano, é acabar de vez com o que ele tem de original e metê-lo como reboque no Carnaval carioca. [...] convém que os vereadores pernambucanos meditem nas minhas palavras e, se querem o Carnaval do Recife com sua originalidade, com suas características inimitáveis, evitem qualquer referência, no projeto às <Escolas de Samba> porque equivalem a um câncer no frevo. (JORNAL DO COMMERCIO, 07/01/56, p. 2).

Ex-secretário da Federação Carnavalesca ${ }^{23}$, Melo acreditava que a oficialização das escolas de samba no Carnaval de Recife prejudicaria o frevo, manifestação entendida como o

\footnotetext{
${ }^{23}$ A Federação Carnavalesca foi um órgão criado em 1935 por um grupo de pessoas ligadas à esfera do poder local, gente de poder político, econômico e de prestígio social. A Federação Carnavalesca tinha por objetivo a organização do carnaval do Recife. A meta era moldar o carnaval recifense ao que denominavam de "tradicionalismo histórico da festa". Tornou-se o órgão responsável por recolher, junto ao comércio, os recursos para a organização da festa. Assim, as agremiações que desejassem receber verbas para organizar suas apresentações no dia de Momo deveriam se enquadrar ao ideário proposto pela Federação, caso contrário era vetada sua participação, bem como receber o pecúlio para a promoção de suas atividades momescas. Sobre a atuação da Federação carnavalesca no carnaval em Recife ver VIDAL, F. M. C. A fresta do Estado e o brinquedo para os populares: histórias da Federação Carnavalesca Pernambucana. Dissertação (Mestrado em História). Universidade Federal de Pernambuco. Recife, 2010.
} 
símbolo máximo da cultura local ${ }^{24}$ e nada nem ninguém poderia ameaçar a soberania do ritmo da terra. Evocou a defesa dos regionalismos: "As infiltrações prejudicam fundamentalmente o regionalismo". (JORNAL DO COMMERCIO, 13/01/56, p. 2). Para o jornalista, o lugar da escola de samba é de onde provinham, do Rio de Janeiro. No entanto, o samba estava presente no Recife há anos e não apareceu apenas no período da oficialização do tríduo momesco. Será que a sua aceitação não estava no fato de as escolas de samba passarem a receber um pecúlio dos cofres públicos? Como os próprios jornais já noticiavam, seus desfiles vinham se destacando na cidade e atraindo um grande número de foliões para suas apresentações. A subvenção recebida não iria fortalecê-las?

Mário Melo salientou que os vereadores não estavam interessados em preservar a cultura local e preocupavam-se com questões eleitoreiras, visto que as escolas de samba representavam um grande reduto de clientelismo. Segundo Melo, se realmente o poder legislativo fosse composto por indivíduos imbuídos da defesa do folclore pernambucano, não hesitariam em reorganizar e corrigir o erro que cometeram ao oficializar escolas de samba no Carnaval de Recife, asfixiando tradições. (FOLHA DA MANHÃ, 12/01/1956, p. 4).

Para se ter uma ideia da importância de Mário Melo na sociedade local da época, uma comissão de vereadores foi formada para ir à casa do jornalista com o objetivo de convencê-lo da importância da lei aprovada: ela não descaracterizaria o Carnaval, ao contrário: lhe permitiria mais oportunidades de brilhantismo inédito. (CORREIO DO POVO, 19/01/1956, p. 2). Porém, Melo estava convencido de que as escolas de samba "representavam um espúrio, uma infiltração perniciosa na tradicional festa de momo recifense" e que o frevo poderia desaparecer diante dessa pressão. Assim discorreu sobre como deveria ser feita a oficialização dos festejos de Momo:

[...] preservando seu folclore: maracatus centenários, clubes de frevo cinquentenários, caboclinhos cinquentenários e não infiltrações perniciosas (exóticas escolas de samba) excrescências do samba. (FOLHA DA MANHÃ, 15/01/1956, p. 4).

As críticas de Melo ao processo de oficialização do Carnaval com a presença do samba provocavam tamanho alarido que os vereadores vinham aos jornais responder às suas indagações, gerando um debate nos periódicos. O Presidente da Câmara de vereadores da época chegou a publicar um editorial para responder às colocações do jornalista, que foi veementemente combatido por Melo.

\footnotetext{
${ }^{24}$ Nesse período, Mário Melo funcionou como uma espécie de "arauto" da intelectualidade. Este grupo, evidentemente, divergia em alguns aspectos, mas no que tange ao tema das escolas de samba esses sujeitos eram coesos em suas ideias.
} 


\section{O Carnaval da Rua da Guia}

A Rua da Guia, por seu Presidente, citando meu nome, como que em resposta a meus artigos, porém, na verdade para dizer que não se reunirá extraordinariamente. Aliás, era sabido que, não havendo remuneração aos vereadores em reuniões extraordinárias, nem estoque de <marmelos>, não haveria interesse para que se abalassem de casa. Este o principal motivo de não quererem reunião extraordinária. A <leite de pato> e sem o tacho no fogo para infusão de <marmelos>, não lhes interessam os problemas municipais. Toda gente sabe que a infiltração do samba no carnaval pernambucano é coisa recente, oriunda da segunda grande guerra é que, se não for contido em tempo, bem poderá expelir o que é nosso, regionalismo nosso. [...] Como se fosse pouco, se não bastasse a oficialização das Escolas de Samba, organizou esse conselho eleitoralmente um representante da Federação, um representante dos Cronistas, um das Escolas de Samba e três da Rua da Guia. De início, quatro votos do Conselho, um do samba e três da Rua da Guia, contra dois. (JORNAL DO COMMERCIO, 15/01/56, p. 2).

Mário Melo afirmava que, caso as escolas de samba fossem oficializadas, teríamos “então um Carnaval amargo, pífio, descaracterizado" e associa a dança a algo contrário à masculinidade. "É melhor não termos o Carnaval de rua, o Carnaval tipicamente pernambucano, a vermos o samba imperando em nossos logradouros, com aqueles indivíduos de sexo duvidoso e ademanes (sic) que horripilam a dignidade masculina". (JORNAL DO COMMERCIO, 17/01/56, p. 2). Para ele, quando as exóticas escolas de samba fossem oficializadas nos festejos, estes estavam fadados a desaparecer. A inclusão das escolas de samba na subvenção da prefeitura e a possibilidade do crescimento desta prática cultural eram encarados por Melo como a própria morte de Momo.

\section{O Carnaval que passou}

As escolas de samba, que a Câmara da Rua da Guia eleitoralmente incluiu na oficialização do Carnaval Recifense, já ocasionaram malefício em nosso folclore, como pode ser apreciado por quem assistiu ao desfile da chamada <Gigantes do Samba>. Entre parênteses: quando se aproximou do palanque oficial, no domingo à noite, foi passado o microfone a um locutor de rádio que, entre palavras ocas sobre as <escolas de samba>, disse que elas representavam tradição no Carnaval pernambucano. Não sei como o palanque não se desmoronou, quando proferida semelhante heresia! Fechado o parêntese. Dizia eu que as exóticas escolas de samba, haviam já produzido seu mal nas agremiações recifenses. Lembram-se os que conheceram nosso Carnaval antes do aparecimento em nossas ruas desse quisto mimosamente acolhido para Rua da Guia, [...] (JORNAL DO COMMERCIO, 16/01/56, p. 2).

O que deveria ser preservado e oficializado para o intelectual eram os clubes de frevo, os cordões, os blocos, os maracatus, os caboclinhos, pois esses grupos representariam o tradicionalismo do Carnaval recifense. Os sambistas tiveram sua manifestação inclusa como prática partícipe dos festejos, mesmo diante da pressão exercida por intelectuais. Entretanto, 
foi criada uma lista hierárquica das agremiações na qual as escolas de samba passaram a figurar na última posição, recebendo a menor porcentagem da verba destinada pelo governo municipal ao patrocínio da festa.

\section{Considerações: para tudo não se acabar na quarta-feira de cinzas!}

O Carnaval é uma festa plural. É impossível ter conhecimento de todos os diversos significados que os foliões atribuíram aos dias de folia durante o recorte temporal pesquisado (1955-1956). Não tive intenção de "julgar" os intelectuais que criticavam a presença das escolas de samba na festa de Momo recifense. Procurei interpretar o sentido de tradição que estavam defendendo quando emitiram determinados discursos, pois "Cada época elenca novos temas que, no fundo, falam mais de suas próprias inquietações e convicções do que de tempos memoráveis, cuja lógica pode ser descoberta de uma só vez” (SCHWARZC, 2001, p. 7).

Busquei tornar mais inteligíveis as lutas cotidianas entre projetos de controle simbólico sobre a festa. A fim de situar aqueles alegres dias de Momo como não tão pacíficos e coloridos assim, esforcei-me em descortinar que em torno deles havia disputas pelo cenário a ser construído. Constatei que o discurso de "terra do frevo" foi fruto de uma construção que encobriu inúmeras memórias. É papel da história mexer com aquilo que é entendido e dado como natural. Compreendi que o desfile das escolas de samba no Recife mostrou-se atrelado a conflitos que foram silenciados em nome de uma história local oficial. A imagem propalada do Carnaval recifense como "terra do frevo" foi construída encobrindo-se várias tensões. Procurei enunciar que essas autenticidades exclusivistas e reducionistas buscam determinar a morte de outras manifestações consideradas estrangeiras e desvirtuadoras de uma cultura local.

Pude visualizar outra Recife, situando-a como uma urbe que se colocava em disputas: disputas pela memória a ser instituída como oficial. Busquei fios que deram forma a sentidos atribuídos ao Carnaval por alguns intelectuais, majoritariamente o jornalista Mário Melo, indivíduo que construiu inúmeras possibilidades de significados aproximando-se/afastando-se do processo de construção da pernambucanidade.

\section{REFERÊNCIAS BIBLIOGRÁFICAS}

ALBUQUERQUE JÚNIOR, Durval Muniz de. "Um morto vestido para um ato inaugural": procedimentos e práticas dos estudos de folclore e cultura popular. São Paulo: Intermeios, 2013. 
A Invenção do Nordeste e Outras Artes. 4. Ed. rev. São Paulo: Cortez, 2009.

ALVES, Bernardo. A Pré-História do samba. Petrolina: Edição do Autor, 2002.

ARAÚJO, Rita de Cássia Barbosa de. Festas: Máscaras do Tempo. Entrudo, mascarada e frevo no carnaval do Recife. Recife, Fundação de Cultura da cidade do Recife, 1996.

BOBBIO, Norberto. Os Intelectuais e o Poder. São Paulo: UNESP, 1997.

CAPONE, Stefania. A Construção da África no Candomblé. Rio de Janeiro: Contracapa/Pallas, 2004.

CUNHA, Fabiana Lopes da. Da Marginalidade ao estrelato. O Samba na construção da Nacionalidade (1917 - 1945). São Paulo: Annablume, 2004.

FERRAZ, Marilourdes. Aníbal Fernandes: jornalista - Nos caminhos da liberdade. Associação da Imprensa de Pernambuco. Recife: CEPE, 1996.

FOUCAULT, Michel. "Nietzsche, a genealogia e a história", In: Microfísica do Poder. Organização e tradução de Roberto Machado. Rio de Janeiro: Graal, 1979.

HOBSBAWM, Eric \& RANGER, Terence (Orgs). A Invenção das Tradições. 6. Ed. Rio de Janeiro: Paz e Terra, 2008.

GUILLEN, Isabel C. M. Maracatus-nação entre os modernistas e a tradição: discutindo mediações culturais no Recife dos anos de 1930 e 1940. CLIO. Série História do Nordeste (UFPE). Recife, v. 01, n.21, p. 107-135, 2003.

LIMA, Ivaldo Marciano de França. Entre Pernambuco e África. História dos Maracatusnação do Recife e a espetacularização da cultura popular (1960 - 2000). Tese de Doutoramento em História, UFF, Niterói, Rio de Janeiro, 2010.

LÖWY, Michel. Para uma sociologia dos intelectuais revolucionários. São Paulo: Ciências Humanas, 1979.

MAIA, Clarissa Nunes. Sambas, batuques, vozerias e farsas públicas. O controle social sobre os escravos em Pernambuco no século XIX. (1850 - 1888). São Paulo: Annablume, 2008.

MONTENEGRO, Antônio Torres. História, Metodologia, Memória. São Paulo. Editora: Contexto, 2010.

MOURA, Roberto M. No Principio era a roda: um estudo sobre samba, partido alto e outros pagodes. Rio de Janeiro: Rocco, 2004.

ROSTAND, Paraíso. Cadê Mário Melo. Recife: COMUNIGRAF, 1997.

SANDRONI, Carlos. O Feitiço Decente. Transformações do Samba no Rio de Janeiro (1917 - 1933). Rio de Janeiro: Jorge Zahar Ed.: Ed. da UFRJ, 2001.

Tradições e suas controvérsias no Maracatu de Baque Virado, In: GUILLEN, Isabel. C. M. (Org.). Inventário Cultural dos Maracatus. Recife: Ed. da UFPE, 2013.

SCHWARZC, Lilia Moritz. Apresentação, In: BLOCH, Marc. Apologia da História: ou o ofício do historiador. Tradução: André Telles. Rio de Janeiro: Jorge Zahar Ed., 2001.

SILVA, A. N. "Intelectuais e tradição: disputas pelos dias de momo no Recife (1955-1956)", In: História e Contemporaneidade. Lucas Victor Silva; Janaína Guimarães e Bruno Melo (Organizadores). Recife: Editora da UFPE, 2015.

E o Recife sambou: disputas e conflitos em torno das primeiras escolas de samba. Saeculum (UFPB), v. 27, p. 123-141, 2012. 
. “Quem gosta de samba, bom pernambucano não é? ”. 2011. Dissertação (Mestrado em História), Universidade Federal de Pernambuco, Recife.

Debate Historiográfico sobre as escolas de samba em Recife (1955 - 1970). 2009. Monografia (Conclusão de Bacharelado em História). Universidade Federal de Pernambuco, Recife.

TINHORÃO, José Ramos. Os Sons de Negros no Brasil. Cantos, danças folguedos: origens. 2. ed. São Paulo: Ed. 34, 2008.

VIANNA, Hermano. O Mistério do Samba. 6. ed. Rio de Janeiro, Jorge Zahar Editores, UFRJ, 2007.

VIDAL, F. M. C. A fresta do Estado e o brinquedo para os populares: histórias da Federação Carnavalesca Pernambucana. Dissertação (Mestrado em História). Universidade Federal de Pernambuco. Recife, 2010.

VOVELLE, Michel. Os Intermediários Culturais, In: Ideologias e Mentalidades. Tradução de Maria Julia Cottvasser. 2. ed. São Paulo: Brasiliense, 1991.

\section{FONTES DOCUMENTAIS}

\section{Periódicos utilizados}

Correio do Povo: janeiro de 1956

Folha da Manhã: janeiro de 1956

Jornal do Commercio: janeiro e fevereiro de 1956

\section{Leis e Decretos Leis Utilizados}

Lei $N^{\circ} 3.346 / 55$

Decreto Lei $N^{o} 1.351 / 56$

ARTIGO ENVIADO EM: 03/03/2015

ACEITO PARA PUBLICAÇÃO EM: 25/05/2015 